\title{
UTILIZING STORY MAPPING STRATEGY TO IMPROVE STUDENTS' READING COMPREHENSION IN FINDING MAIN IDEA
}

\author{
Roihatul Millah \\ Politeknik Negeri Media Kreatif \\ roihatulmillah@gmail.com
}

\begin{abstract}
This research aims at (1) finding out whether Story Mapping Strategy can improve students' reading comprehension in finding main idea and (2) describing classroom climate when Story Mapping Strategy is implemented. The preliminary research showed that the students had problems in determining the main idea and finding the supporting details of the main idea. The method of this research was CAR and it was conducted in three cycles. In collecting the data, the researcher used observation field note, interview, questionnaire, diary, and test. Then, the researcher analyzed quantitative and qualitative data. The first were analyzed by using descriptive statistic (DS). It compared between the mean score of pre-test (before treatment) and post-test 1, 2, and 3 (after treatment). The later were analyzed by using Constant Comparative Method (CCM). The result of the research showed that (1) Story mapping strategy can improve the students' reading comprehension in finding main idea.(2) Story mapping strategy can improve the classroom climate in terms of: (a) students' cooperation is maximal and alive because they are motivated, helped, and encouraged, (b) students were more enthusiastic, got custom in story mapping and main idea activity, and could participate well because they often get praise or appreciation in classroom activity.
\end{abstract}

Key Words: Story mapping strategy; Reading comprehension; Main Idea; Action Research

\section{INTRODUCTION}

In teaching and learning English, there are four language skills to be mastered: listening, speaking, writing and reading. Among those skills, reading is the skill that is commonly first taught or learnt when someone studies a foreign language in educational institution. Reading becomes a significant skill considering the need of understanding the reading text information. Richards and Renandya (2002:288) say that reading is one of a number of skills courses that supplement a content. Students may find a lot of information in written language.

However, reading is a complex activity.According to Dawson and Bamman (1967:2): "Reading is many-sided complex activity". Reading a foreign language is even more difficult, mainly because of the different language structure between the target language and the mother tongue. Indonesian students often consider reading as a difficult language skill to 
learn. They have difficulties in comprehending the reading text. They often fail in English test of reading comprehension. Nevertheless, the comprehension must be taught in teaching reading because comprehension is the important part in reading process. Besides, comprehension is the reason for reading. If readers can read the words, but not understand the meaning of what they are reading, they are not really reading. The purpose of reading comprehension is basically to look for information in the reading text, so the teacher must guide the students on how to do it.

Based on the preliminary observation in SMA Kemala Bhayangkari 1 Jakarta, the researcher realizes that the students have the problems in reading comprehension especially in finding main idea. In pre-test, there are five reading indicators that must be achieved by students, they are: finding main idea, determining the purpose of text, finding detail information, determining word meaning, and finding reference. After conducting the pre-test, the researcher finds that most of the students get difficulty in finding main idea. The mean of finding main idea indicator is the lowest. It is about $47.78 \%$. This problem occurs because of some problem indicators: They are: (1) the students are confused to determine the main idea of the text and each paragraph and (2) the students have difficulty in finding the supporting details of the main idea in each paragraph. Therefore, the researcher focuses on students' difficulty in finding the main idea.

To know the students' difficulty in finding main idea more detail, the researcher conducts the second pre-test consisting of two main idea indicators. Details score can be seen in the table below.

Table 1. The Mean Score of Each Main Idea Indicator

\begin{tabular}{|c|l|c|c|}
\hline No & \multicolumn{1}{|c|}{ Indicators } & $\begin{array}{c}\text { Total } \\
\text { Items }\end{array}$ & Mean \\
\hline 1. & Determining main idea of the text and each paragraph & 15 & 55.78 \\
\hline 2. & $\begin{array}{l}\text { Finding the clues or supporting details of the main idea in } \\
\text { each paragraph }\end{array}$ & 15 & 68.89 \\
\hline & Total & 30 & 124.67 \\
\hline & Mean & & 62.33 \\
\hline
\end{tabular}

The data above shows that the mean score in determining main idea of the text and each paragraph is 55.78, the mean score in finding supporting details of the main idea in each paragraph is 68.89 , and the total means score of two main idea indicators is 62.33 . It means that the students' reading comprehension in finding main idea is below the Minimum Passing Grade of KKM (Kriteria Ketuntasan Minimum). 
Meanwhile, classroom climate also impacts the students' score. To know the classroom situation, the researcher observes the teaching learning process in reading class. The researcher finds that the cooperationamong students looked not alive because teacher rarely put the students in group discussion, so the atmosphere was not interactive and fun. Besides, the teacher rarely gave motivation, help, support, and encouragement in order to get the students' interest in teaching learning process, so some students did not give full attention to teacher's explanation and felt uninterested to the lesson. The teaching learning process in teaching reading also used conventional method. The students were taught by using LKS (LembarKerja Siswa) then the students were asked to read the text and answer the following questions without knowing enough the content of the text. The reading class often started with reading text aloud and finding out the difficult word at dictionary. This situation made the students were not enthusiastic in doing the task in classroom activity. Besides, some of the students did not participate well, they were busy with themselves, and did not focus on teaching and learning process. Moreover, the students thought that teacher rarely gave them praise when they could answer the question and joined the teaching learning process actively. This situation is supported by the following interview:

Researcher: "Does the teacher use various and unconventional methods in teaching reading?"

Student 1: "The teacher never uses it. She just uses LKS".

Student 2: "Never, the teacher just speaks in front of the class and if we do not understand the vocabulary, the teacher asks us to open dictionary".

Student 3: "The teacher asks us to read aloud the text in front of the class".

Student 4: " The teacher hasn't used various methods and it is boring".

Researcher: "Does the teacher motivate the students in reading class?"

Student 2: "No, she doesn't. The teacher cannot socialize well with us in the class."

Student 6: "The teacher rarely motivates us in reading the text".

Student 7: "Sometimes, the teacher motivates us in the class".

Those problems arise because of some causes. They are divided into two sides: internal and external factors. The internal factors are: (1) the students tend to lose the focus in reading class; (2) the students have limited vocabulary in understanding the text; (3) some of the students are confused in understanding the elements of the text; and (4) the students rarely read English reading text outside the class. Then, for the external factors are: (1) the materials are not interesting and monotonous; and (2) the teachers are not aware of the various media and techniques used in teaching and learning process. Actually the teacher must find the solution for the problem above, so that the students' achivement in reading comprehension is better. 
Considering the fact, the researcher decides to find out the solution by conducting the new method or strategy in teaching reading comprehension. The researcher proposes a research by utilizing story mapping strategy as a solution and an interesting strategy to improve students' reading comprehension in finding main idea. The researcher will also use the narrative text during the research because based on the result of the students' interview, some students state that narrative text is a difficult text to be understood. Therefore, the researcher wants to solve the students' difficulty in finding main idea of narrative text by using story mapping strategy. The result of the students' interview:

Researcher:"What is the difficult reading text to comprehend?"

Student 1: "Narrative text"

Student 7: "Narrative"

Researcher:"What do you think of narrative text?"

Student 9: "It's not easy to understand narrative text"

Student 10: "Confusing"

Story mapping is one of the strategies in teaching reading which can be applied to overcome the problem. Story mapping is a teaching strategy that can improve the students' reading comprehension. It will help students to comprehend text by finding information inside the text especially in narrative text. Story Mapping is based on the schema theory of reading comprehension, which proposes that adequate comprehension depends on the reader's ability to link previous knowledge structures (schemata) with textual material (Anderson, Spiro, \& Anderson; Singer \& Donlan in Rathvon 2008: 212). In addition, according to Duman quoted by Isikdogan and Kargin (2010: 4): "Story map is a schema construction technique that involves teaching the relationships of parts of a story to the reader and giving basic elements of the story in a schema in order to draw the attention of the reader". When the students are interested in this learning process, it can motivate them to comprehend the reading text. Actually, It is not easy for students to comprehend reading text. Therefore, they need a strategy to help them in comprehending it. Blachowicz and Ogle quoted by Wodrich and Schmitt (2006:79) convey that story mapping strategy is also suggested for children with reading comprehension difficulties. Diminoet al in Burke (2004) also state that story maps have been utilized to increase reading comprehension skills by prompting students to recognize story-grammar elements such as character, setting, and problem.

Story maps are often implemented in enhancing reading comprehension especially in narrative text. According to Wright (2003): "Story mapping is a procedure which trains students to recognize the basic framework of narrative story in order to enhance their comprehension". Story maps enhance reading comprehension by helping students to store 
and retrive information, make connection between previous experience and reading materials, identify relationship among concept and event, organize specific details and understand the message embedded in the text.

Considering the advantages above or how the story mapping works as one of the strategies to solve the reading comprehension's problem that faced by the students, the researcher believes that Story Mapping strategy can improve the students' reading comprehension in finding main idea at the eleventh grade students of SMA Kemala Bhayangkari 1 Jakarta in 2012-2013 Academic Year.

From the description of the background above, the problems formulated in this research are: first, can Story Mapping Strategy improve the students' reading comprehension in finding main idea? If yes, to what extent is its improvement? Second, how is the classroom situation when Story Mapping Strategy is implemented in class?

Based on the formulation of the problem above, the objectives of the research are: first, to find out whether Story Mapping strategy can improve the students' reading comprehension in finding main idea and to describe its improvement; second, to describe classroom situation when Story Mapping strategy is implemented in class.

\section{LITERATURE REVIEW}

The discussion of reading cannot be separated from the definition of reading itself. Urquhart and Weir quoted by Grabe (2008: 14) points out: "Reading is the process of receiving and interpreting information encoded in language form via the medium of print". Moreover McGinnis and Smith (1982: 13) define reading as a purposeful process of identifying, interpreting, and evaluating ideas in terms of the mental content or the total awareness of the reader.

The reason of reading is to comprehend the text or to get information inside the text. Comprehension is the primary purpose of reading. Grabe in Richard and Renandya (2002: 277) states that the primary purpose of reading is reading for comprehension, raising student awareness of main ideas in a text and exploring the organization of a text are essential for good comprehension.Besides, Mc Shane (2005:71) defines that reading comprehension is to get understanding of meaning after reading. Savage and Mooney (1979:1) also state, "Reading comprehension is a process of acquiring or deriving meaning and understanding of printed language; involves cognitive functioning related to what one reads." Furthermore, Pamela et al. (2004:3) points out that reading comprehension is the process of understanding the message that the author is trying to convey. In a simple way, it is making meaning from 
the text at hand. Therefore, reading comprehension is a process to understand, acquire, derive, convey, and construct the meaning, message, and information in the written text involves cognitive functioning related to the reader. In line with the reading purpose, infer links and connections between events, deduce causes and effects, and detect such relations as main idea, supporting idea, new information, given information, generalization, and exemplification as the reading objective in senior high school (Brown, 2003: 187-188).

Finding main idea is one of the reading indicators. It is also an essential part in comprehending the reading text. There are some definitions of main idea. Chesla (2001: 12) says that main idea is the overall fact, feeling, or thought a writer wants to convey about his or her subject. Besides, Gunning (2010: 24) conveys that the main idea is a summary statement that includes the details or ideas in a selection. It is what all the other sentences are about. Meanwhile, Duffy (2009: 138) states that main idea refers to the big idea or the most important idea found in the text.

Besides, main idea can be found in every paragraph of the text. A sentence that expresses the main idea of a paragraph is called a topic sentence (Chesla, 2000: 61). "Learning Assistance Center" (2010) conveys that topic sentence is statement of the main idea. Topic sentences are usually in the first sentence of the paragraph, but not always. They may also be located within the paragraph or at the end of the paragraph. Therefore, a sentence that clearly expresses the main idea of a paragraph or passage is often called a topic sentence.

Actually, in understanding the main idea, the reader needs supporting details that provide specific facts and details. According to "Learning Assistance Center" (2010): " Supporting detail is a sentence contains facts, statements, examples-specifics which guide us to a full understanding of the main idea". It means that to clarify, illuminate, explain, describe, expand and illustrate the main idea, the reader need supporting details.

It can be concluded that in comprehending the reading text, the reader should understand the main idea, topic sentence, and supporting details. The main idea must be in general information that covers all ideas in the passage. Besides, the main idea can be found in every paragraph of the text. It often finds at the beginning of paragraph, may also find within the paragraph, and at the end of paragraph. A sentence that expresses the main idea of paragraph is called a topic sentence. Besides, the reader needs supporting details that provides specific facts and details in understanding the main idea of the text.

To make the students interested and to improve the students' reading comprehension in finding main idea, the teacher should be able to provide various strategies that are appropriate with the students' need, interest, and learning objectives. One of the strategies is story 
mapping strategy. Antonnaci and O'Callaghan (2012: 122) say that the story mapping strategy provides a visual display of story elements that will assist readers in remembering, comprehending, and retelling the story they listen to and read. Story maps offer visual representations of the part of a story that help students navigate their way through the story, from the beginning to the end of the text. The diagram facilitates students in aqcuiring a story sense that assist them in comprehending the story through the map's organized representation of the stucture of narrative text. Clearly, reading with story maps support students in organizing their ideas around the elements of the text, thereby helping them comprehend stories at deeper levels.

Similar view is purposed by Beck and McKeown as quoted by Buehl (2008: 166): "Story mapping helps students track their knowledge of narrative structure to analyze stories. Educators agree that students' use of story maps during reading will develop their comprehension or visualization strategies for narrative text (Fience and McMahon in Antonacci and O'callaghan (2012: 122). Moreover. Reutzel in Amer (2003: 66) found story maps to be a good alternative to the traditional question and discussion session following the reading of a story. They enhance reading comprehension by helping students to store and retrieve information, make connections between previous experience and reading materials, identify relationships among concepts and events, organize specific details, and understand the message embedded in the text.

In conclusion, in teaching reading comprehension of narrative text, story mapping is a strategy that helps students to train their previous experience and knowledge to enhance their comprehension and analyze the elements of the story. Cooper in Amer (2003: 64) presents the elements of story mapping that consist of a setting, characters, a problem, action, event, resolution, and theme.

\section{RESEARCH METHODS}

The subject of the research is the eleventh grade students of science class SMA Kemala Bhayangkari 1 Jakarta, at the odd semester of 2012-2013 academic year. It consists of 30 students, 21 females and 9 males.

The method used in this research is Classroom Action Research (CAR). Kemmis and McTaggart in Jack C. Richards (1996: 12) that action research refers to teacher-initiated classroom investigation which seeks to increase the teacher's understanding of classroom teaching and learning, and to bring about change in classroom practices. Action research 
consists of a number of phases which often recur in cycle: planning, action /implementing, observing, and reflecting.

The researcher works collaboratively with the teacher. The researcher has a role as a teacher and she asks the English teacher as a collaborator. An action is implemented in order to solve the problem and to improve students' reading comprehension in finding main idea by implementing Story Mapping strategy.

There are three cycles in implementing story mapping strategy. Each cycle consists of four meetings. Each cycle uses different media to support the strategy. The findings after implementing the strategy determine whether the researcher stops or move to the next cycle. It aimed to get the maximum result of the students' improvement in mean score and classroom situation.

There are two types of data collection of the research, namely, quantitative and qualitative. The quantitative data were collected by conducting pre-test and post-test in reading comprehension in finding main idea. Meanwhile, the qualitative data were collected by observation, interview, questionnaire, and diary. Having collected the data, the researcher analyzed quantitative and qualitative data. The quantitative data were analyzed by using descriptive statistic (DS). It compares between the mean score of pre-test (before treatment) and post-test 1, 2, and 3 (after treatment). The qualitative data are analyzed by using Constant Comparative Method (CCM) which consists of comparing incidents applicable to each category, integrating categories and their properties, delimiting the theory, and writing the theory.

\section{FINDINGS AND DISCUSSION}

The result of utilizing story mapping strategy showed that the students' reading comprehension in finding main idea improved. The improvement could be identified by comparing the mean score between pre-test, post-test 1, post-test 2, and post-test 3 . The details result is described in the table below:

Table 2. The Mean Score between Pre-test, Post-test 1, Post-test 2, and Post-test 3

\begin{tabular}{|l|l|c|c|c|c|}
\hline No & \multicolumn{1}{|c|}{ Indicators } & Pre-test & Post-test 1 & Post-test 2 & Post-test 3 \\
\hline 1. & $\begin{array}{l}\text { Determining main idea of } \\
\text { the text and main idea in } \\
\text { each paragraph }\end{array}$ & 55.78 & 62.89 & 69.56 & 75.11 \\
\hline 2. & Finding the clues or & & & & \\
\hline
\end{tabular}




\begin{tabular}{|l|l|c|c|c|c|}
\hline & $\begin{array}{l}\text { supporting details of main } \\
\text { idea in each paragraph }\end{array}$ & 68.89 & 74 & 76 & 80.67 \\
\hline Total Mean & 62.33 & 68.33 & 72.78 & 77.89 \\
\hline
\end{tabular}

Based on the table above, it can be concluded that there was improvement of the students' reading comprehension in finding main idea from pre-test to post-test 1 , post-test 2 , and post-test 3 . The total mean score improved from cycle to cycle. The total mean in pre-test was 62.33 improved into 68.33 (post-test 1). It also improved into 74.44 (post-test 2) and the last mean score was 79.33 (post-test 3).

The level of students' reading comprehension in finding main idea also improved. It could be seen in the following table:

Table 3. The level of the Students' Reading Comprehension in Finding Main Idea

\begin{tabular}{|c|c|c|c|c|c|}
\hline \multirow{2}{*}{$\begin{array}{c}\text { Percen- } \\
\text { tage }\end{array}$} & \multirow{2}{*}{$\begin{array}{c}\text { Interpre- } \\
\text { tation }\end{array}$} & \multicolumn{4}{|c|}{$\begin{array}{c}\text { Number of Students } \\
\text { (N: 30) }\end{array}$} \\
\cline { 3 - 6 } & $\begin{array}{c}\text { Pre- } \\
\text { test }\end{array}$ & $\begin{array}{c}\text { Post- } \\
\text { test 1 }\end{array}$ & $\begin{array}{c}\text { Post- } \\
\text { test 2 }\end{array}$ & $\begin{array}{c}\text { Post- } \\
\text { test 3 }\end{array}$ \\
\hline $81-100$ & Very Good & - & - & - & 5 \\
\hline $66-80$ & Good & 14 & 20 & 27 & 25 \\
\hline $56-65$ & Fair & 10 & 10 & 3 & - \\
\hline $41-55$ & Poor & 6 & - & - & - \\
\hline $0-40$ & Very Poor & - & - & - & - \\
\hline
\end{tabular}

Based on the table above, it describes that the level of the students' reading comprehension in finding main idea improved. The number of students in poor and fair level decreased and the number of students in good and very good level increased after implementation the treatment.

Another point of the students' improvement was about the percentage of the students who got the score above the minimum passing grade of KKM. There are $30 \%$ students in preliminary, $50 \%$ students in cycle 1, $80 \%$ students in cycle 2 , and $100 \%$ students in cycle 3 .

The improvement after implementing story mapping strategy also impacts to the classroom climate. Before implementation this strategy, the students' cooperation looked not alive, however after implementation this strategy the students' cooperation looked maximal and alive. The silent students also became more active because in group work they could 
share their ideas and there was any interaction between the members of the groups. Besides, in pre-research also showed that the teacher rarely gave motivation, help support, and encouragement in order to get the students' interest, however after implementing the strategy, the positive responses occurred from students because the researcher who worked as a teacher often gave them motivation, help, support, and encouragement. In addition, the students who felt bored and not interested in reading activity became active, after the teacher implemented this strategy supported by some media and positive encouragement. Moreover, before implementation of this strategy, the students looked not enthusiastic in doing the task and did not participate well in classroom activity. However, after implementation this strategy, most of the students looked more enthusiastic in doing the task and could participate well in classroom activity. The teacher also gave them good appreciation when they are active in teaching and learning process. Therefore, the researcher concluded that by utilizing story mapping strategy, most of the students could enjoy the reading text especially the narrative text and they could participate in all activities so that, it could help them to improve their score of reading comprehension in finding main idea especially in narrative text.

The discussion of the theories is described in the following section.

\section{a. Story Mapping Strategy can improve students reading comprehension in finding main idea especially in narrative text.}

The findings of the research showed that story mapping strategy can improve students' reading comprehension. The students can comprehend the text if they know the elements of the text. Diminoet al in Burke (2004) state that story maps have been utilized to increase reading comprehension skills by prompting students to recognize story-grammar elements such as character, setting, and problem. Moreover, the elements of the text help the students with learning difficulties to comprehend the text. Bender and Larkin (2009: 169) convey that story mapping can provide the much-needed stucture for students with learning difficulties to comprehend stories and passages that they read.

The text structure is a part in reading texts especially in narrative text. Carrasquillo, Kucer, and Abrams (2004: 74) state that narrative text is found in stories and has a structural organization that includes a beginning, a middle, and an end of the story. Around this organizational structure may be built several story episodes comprising characters, setting, problem, goal, actions, and resolution/solution. These elements are called story grammar - a basic plan around which the story parts are interelated. The use of story maps will help students to understand the stucture of narrative text and the elements of story grammar. According to Walpole and Mckenna (2007: 116): "Story mapping teaches students to focus 
attention on setting, characters, problem-solution-outcome, reaction, and theme to help them comprehend, remember, and retell narative". Educators agree that students' use of story maps during reading will develop their comprehension or visualization strategies for narrative text (Fience and McMahon in Antonacci and O'callaghan (2012:122). The purpose of the story map method is to have students construct the story about the elements of the story in their minds without using the given visual material as story map after a certain time and to improve thinking structures that provide text comprehension (Sorrell in Isikdogan \& Kargin, 2012: 4).

Furthermore, according to Webster (2012): "Story Maps are used for teaching students to work with story structure for better comprehension. This technique uses visual representations to help students organize important elements of a story. Students learn to summarize the main ideas, characters, setting, and plot of an assigned reading". The Story Map Method is accepted as an effective technique in distinguishing significant and insignificant information in the story, directing students (making them focus on important components), providing active participation, transferring information into long term memory, activating foreknowledge, and predicting (Akyol in Isikdogan \& Kargin, 2010: 4). In addition, according to Webster (2009: 3): "Students can use the list Story Map to get clarity on the setting(s) of a story; the main character(s); the primary conflict, problem, or situation and how it is resolved; and details relevant to the main idea of the story. Therefore, story mapping can enhance reading comprehension in finding main idea by helping students to store and retrieve information, make connections between previous experience and reading materials, identify relationships among concepts and events, organize specific details, and understand the message embedded in the text.

\section{b. Story mapping strategy can improve the classroom climate}

The classroom climate before the research described that the students' cooperation looked not alive. It happened because they were rarely invited in group work or discussion. The teacher also rarely gave the students support, motivation, and encouragement during instructional process, so it makes the students pay little attention to the teacher's explanation and were busy with themselves. The orientation of task that was given by the teacher was not effective, either. The students are not enthusiastic in doing the task. Besides, the students' involvement in teaching learning process was not alive. Most of them only kept silent and sometimes the class became noisy. They felt lazy to participate in the classroom activity. Moreover, the teacher rarely gave them praise when they did the task well. It makes them felt disappointed to the teacher's response. 
After conducting the research, the researcher found that the class climate looked different. The findings showed that story mapping strategy can improve the class climate. The students can cooperate with their friends well, positive response comes from the students. They can participate actively in the learning process. They paid attention to the teacher's explanation, they looked interested to join the reading class, and the classroom atmosphere also became alive, interactive, and fun

Webster (2009: 3) explains that "Making story maps and summarizing what we have read can be fun and interactive. These two skills help the reader get a bird's-eye view of a story and its events". Whereas, Idol (1987: 197) states that story mapping brings the reader's attention to important and inter-related parts of a narrative story. These story parts can be thought of as a type of story schemata for organizing and categorizing important story components.

Moreover, Idol (1987: 197) adds,

When the reader is instructed about inter-related components or parts of a story, this provides a basic framework that draws the reader's attention to the common elements among narrative stories; thus enlarging the possibility of the reader searching his/her mind for possible information, searching the text for such information, and using the story map as a framework for drawing the two information sources together.

Based on the description above, it can be concluded that story mapping strategy can improve the classroom situation because it encourages the students to understand the text from learning the elements of the text, the students can be more creative to make their own maps, there is interaction between the students in reading activity, the students became active and enjoy the learning activity, and the classroom atmosphere became attractive, alive, fun, and interactive.

\section{CONCLUSION}

After conducting the research by utilizing story mapping strategy to improve reading comprehension in finding main idea among the eleventh grade students of SMA Kemala Bhayangkari 1 Jakarta, the researcher makes the conclusions as follows: (1) story mapping strategy can improve the students' reading comprehension in finding main idea, (2) story mapping strategy can improve the classroom climate.

The result of the research also shows that there is improvement in students' reading comprehension in finding main idea significantly during teaching learning process. Furthermore, the classroom climate also improves. This strategy can involve the students in learning process, so that they do not become passive learners in receiving the information. 
Besides, it can activate the students' prior knowledge of narrative text and create visual description about the story in their mind. The students can understand the content or information of the text easily because they know the elements of the text. Besides teaching reading, teacher can also apply story mapping strategy in writing class. It helps the students to create outline of the new text, so that the writing activity will be interesting. With all strength of the implementation story mapping strategy, the teacher can take the benefit in utilizing this strategy and can reduce the students' difficulty of reading comprehension in finding main idea. Therefore, this research implies that utilizing story mapping strategy can improve students' reading comprehension in finding main idea and classroom climate. It is a suitable way to solve the students' difficulty in comprehending the reading text.

Having conducted this research, the researcher would like to give some suggestions. They are (1) for the English teacher, he should select the appropriate strategy or technique and media with the students' need, level, and learning objectives. In order to improve the students reading comprehension in finding main idea especially in narrative text, the teacher can use Story Mapping strategy. It is suitable way to solve the students' difficulties in reading class. (2) For other teachers, as a conductor of teaching learning process, teachers should be able to know the students' interest and need. It aimed to choose the most suitable and interesting method, strategy, or technique to apply in reading class, so that the students can achieve the learning objective. (3) For the students, they should be aware that comprehending the reading text is not difficult if they have motivation to learn it and involved in teaching learning process well. The students also should develop their reading skill through forming reading habit and enrich their vocabulary consistently to understand the English reading text. Moreover, the students have to pay attention to teacher's explanation and consult when they have any problem. (4) For the principal,he/she should encourages teachers to apply various strategies in teaching learning process, for instance, utilizing story mapping strategy in teaching reading comprehension. The principal also should provide the facilities and training for the teacher to get the maximal result in teaching learning process. (5) For others researcher,hopefully it can be a starting point to the future research and it will be an inspiration to provide appropriate techniques to improve students' reading comprehension in finding main idea. 


\section{REFERENCES}

Amer, A.A. (2003). Teaching EFL/ESL Literature. Journal of the Reading Matrix, 3 (2), 6373.

Antonacci, P.A., \& O'Callaghan, C.M. (2012). Promoting Literacy Development: 50 Research-Based Strategies for K-8 Learners. Los Angles: Sage Publications, Inc.

Bender, W.N., \& Larkin, M.J. (2009). Reading Strategies for Elementary Students with Learning Difficulties ( $2^{\text {nd }} E d$ ). New York: Corwin A SAGE Company

Beuhl, D. (2008). Classroom Strategies for Interactive Learning ( $3^{\text {rd }}$ Ed): The International Reading Association, Inc.

Brown, H.D. (2003). Language Assessment: Principles and Classroom Practices. San Fransisco: Longman.

Burke, M.D. (2004). Use of Story-Mapping to Increase the Story-Grammar Text Comprehension of Elementary Students with Learning Disabilities. Retrievedfromhttp://www.thefreelibrary.com/Use+of+storymapping+to+increase+the+st orygrammar+text+comprehension...-a0121279908

Burns, A. (1999). Collaborative Action Research for English Language Teachers. Cambridge: Cambridge University Press

Carrasquillo, A., Kucer, S.B., \& Abrams, R. (2004). Beyond the Beginnings: Literacy Intervention for Upper Elementary English Language Learners. Clevedon: Cromwell Press Ltd.

Chesla, E. (2000). Read Better, Remember More $\left(2^{\text {nd }}\right.$ Ed).New York: Learning Express

Chesla, E. (2001). $8^{\text {Th }}$ Grade Reading Comprehension Success. New York:. Learning Express

Dawson, M.A.,\&Bamman, H.A. (1963). Fundamental of Basic ReadingInstruction. New York: David Mckay

Duffy, G.G. (2009). Explaining Reading: A Resource for Teaching Concepts, Skills, and Strategies $\left(\left(2^{\text {nd }} E d\right)\right.$. New York: The Guilford Press

Farris, P.J., Carol J.F., \& Maria P.W. (2004). Teaching Reading: A balanced Approach for Today's Classroom. New York: Mac Graw Hill. Hill Companies, Inc

Grabe, W. (2009). Reading in a Second language (Moving from Theory to Practice). Cambridge: Cambridge University press.

Gunning, T.G .(2010). Reading Comprehension Boosters. San Francisco: Josset Bass

Idol, L. (1987). Group Story Mapping: A Comprehension Strategy for Both Skilled and Unskilled Readers. Journal of Learning Disabilities, 20, 196-205. doi: 10.1177/002221948702000401. 
Isikdogan, N.,\& Kargin, T. (2010). Investigation of the Effectiveness of Story- Map Method on Reading Comprehension Skills among Students with Mental Retardation.Journal of Educational Science: Theory \& Practice, 10 (3), 1509-1527.

Learning Assistance Center .(2010). Main Ideas and Supporting Details. Retrieved from manoa.hawaii.edu.

McGinnis, D. J., \& Smith, D. E. (1982). Analysing and Treating readingproblems.New York: Macmillan Publishing Co., Inc.

McShane, S. (2005). Applying Research in Reading Instruction for Adults: First Steps for Teachers. Washington D.C: The National Center Family Literacy.

Ratvon, N. (2008). Effective School Interventions: Evidence-Based Strategies for Improving Student Outcomes ( $\left.2^{\text {nd }} E d\right)$. New York: The Guilford Press

Renandya, W.A.,\& Richards, J.C. (2002). Methodology in Language Teaching. New York : Cambridge University Press.

Richards, J.C. (1996). Reflective Teaching in Second LanguageClassrooms.New York: Cambridge University Press.

Savage, J.F., \& Jean, F.M. (1979). Teaching Reading to Children with Special Needs. London: Inc

Walpole, S., \& McKenna, M.C. (2007). Differentiated Reading Instruction Strategies for Primary Grades. New York: Guilford Press

Webster's Classroom Strategies Story Maps (2012). Washington D.C: WETA

Webster's Main Idea and Supporting Details (2012). New York: Comprehension Publishing

Webster's Reading Comprehension Flip Chart (2009). Retrieved from page.reallygoodstuff.com/pdfs/303700.pdf

Wodrich, D.L.,\& Schmitt, A.J. (2006). Patterns of Learning Disorders. New York: The Guilford Press

Wright,D.B. (2003). Group Story Mapping. Teaching and learning. Retrieved fromhttp://pent.ca.gov/acc/groupstorymapping.pdf 